\title{
Az időskori szédülés életminőségre kifejtett hatása
}

\author{
Molnár András dr. ${ }^{1}$ - Forster Mátyás oh. ${ }^{2}$ - Maihoub Stefani dr. ${ }^{1}$ \\ Tamás László dr. ${ }^{1}$. Szirmai Ágnes dr. ${ }^{1}$
}

\author{
${ }^{1}$ Semmelweis Egyetem, Általános Orvostudományi Kar, Fül-Orr-Gégészeti és Fej-Nyaksebészeti Klinika, Budapest \\ ${ }^{2}$ Semmelweis Egyetem, Általános Orvostudományi Kar, Budapest
}

\begin{abstract}
Bevezetés: A szédülés időskorban gyakori panasz, amely jelentősen befolyásolja az életminőséget. Háttere sok esetben multifaktoriális, egyes esetekben azonban jól meghatározott ok kimutatható,

Célkitüzés: Kutatásunk célja az időskori szédülő populáció panaszainak, valamint életminőségének felmérése volt. Anyag és módszer: Kutatásunkba 36 (13 férfi, 23 nőbeteg, átlagéletkor \pm SD, 72,78 év \pm 4,6), Otoneurológiai Ambulanciánkon szédülés miatt vizsgált, 65 év feletti beteget vontunk be. Ök az általunk összeállított, panaszokkal és rizikófaktorokkal kapcsolatos kérdőív mellett a Dizziness Handicap Inventory-t is kitöltötték. Az utóbbi alapján meghatározható volt az életminőség-romlás, illetve annak mértéke. A statisztikai elemzést az IBM SPSS V24 szoftver segítségével végeztük, Mann-Whitney U-teszt és khi-négyzet-próba alapján. Minden esetben p<0,05 értéket tekintettünk szignifikáns különbségnek.

Eredmények: A leggyakoribb diagnózisként a Ménière-betegséget, valamint a centrális vestibularis eltéréseket detektáltuk. A betegek visszajelzése alapján a szédülés volt a legdominánsabb tünet, amely a leggyakrabban órákig, illetve napokig tartott, és fele arányban volt forgó jellegú. Emellett a fülzúgás, a halláscsökkenés, valamint a vegetatív tünetek is dominánsak voltak. A leggyakoribb társbetegségek közül gyakoriságuk miatt kiemelendők a mozgásszervi, illetve szemészeti eltérések, a hypertonia, valamint a pszichiátriai betegségek. A betegek 77,8\%-a jelzett valamilyen mértékű életminőség-romlást, és kiemelendő, hogy 30\%-uk a súlyos kategóriába esett. A Dizziness Handicap Inventory kérdőívek alapján a fizikális, funkcionális, valamint emocionális részpontszámok hasonló értéket mutattak. Következtetés: Az időskori szédülés lényeges a beteg romló életminősége szempontjából. A társuló komorbiditások mellett a háttérben álló vestibularis eltérések kizárása, illetve diagnosztizálása fontos feladat. Ennek függvényében tervezhető a terápia, amely kapcsán a kísérő tünetekre is fontos hangsúlyt fektetni. Így az érintett betegek életminősége javítható.
\end{abstract}

Orv Hetil. 2021; 162(47): 1891-1896.

Kulcsszavak: időskori szédülés, társbetegségek, életminőség, Dizziness Handicap Inventory kérdőív

\section{The influence of dizziness on the quality of life in elderly}

Introduction: Vertigo is a common complaint in elderly, which has significant influence on the patients' quality of life. In many cases its background is complex, although, in some cases specific diagnosis can be made. Objective: Our study aimed to analyze the symptoms and quality of life of old-age vertiginous population.

Material and method: 36 patients (13 males, 23 females, mean age \pm SD, 72.78 years \pm 4.6 ) over 65 years, examined due to vertigo at our Neurotologic Department, were enrolled. A questionnaire including questions regarding the symptoms, risk factors, along with the Dizziness Handicap Inventory was used. Statistical analysis was carried out using IBM SPSS V24 software. Mann-Whitney U and chi square tests were used. Statistical significance was defined as $\mathrm{p}<0.05$.

Results: Ménière's disease and central vestibular disorders were found as the most frequent diagnoses. Vertigo was the most tormenting symptom, which usually lasted for hours or days, and was defined as rotatory in $50 \%$. Tinnitus, hearing loss and vegetative symptoms were also dominant. The most frequent comorbidities were musculoskeletal disorders, hypertension, ophthalmological diseases and psychiatric disorders. $77.8 \%$ of the patients have reported worsened quality of life, of which $30 \%$ was detected as severe. Based on the Dizziness Handicap Inventory, physical, functional and emotional scores showed similar results.

Conclusion: Vertigo in elderly is important due to its influence on patients' quality of life. Besides comorbidities, the diagnosis of vestibular pathologies is of great importance. Therefore, therapy planning is possible, and patients' quality of life can be improved. 
Keywords: vertigo in elderly, comorbidities, quality of life, Dizziness Handicap Inventory questionnaire

Molnár A, Forster M, Maihoub S, Tamás L, Szirmai Á. [The influence of dizziness on the quality of life in elderly]. Orv Hetil. 2021; 162(47): 1891-1896.

(Beérkezett: 2021. április 1.; elfogadva: 2021. május 4.)

\section{Rövidítések}

$\mathrm{BPPV}=$ benignus paroxysmalis positionalis vertigo; COVID-19 $=($ coronavirus disease 2019) koronavírus-betegség 2019; $\mathrm{DHI}=($ Dizziness Handicap Inventory) szédülésterheltségi skála; $\mathrm{SD}=$ standard deviáció

Korábbi kutatások eredménye alapján a szédülés a 75 év feletti populációban vezető tünetnek tekinthető [1]. A szédülés miatti orvosi látogatások egyéves prevalenciája 60 év felett 20\%, 70 év felett 30\%, míg 80 év felett $50 \%$ értékre tehető [2]. Ez a fejlett országokban megfigyelhető elöregedő populáció miatt kiemelt közegészségügyi kérdés. Ezen panaszok „időskori szindrómaként” való definiálása azonban magában rejti annak veszélyét, hogy a háttérben álló diagnosztizálható és kezelhető okokra nem derül fény [3]. Ebból a megfontolásból egy korábbi tanulmány két lépést határoz meg az időskori szédülés ellátásában: a háttérben álló, kezelhető elváltozások diagnosztizálását, valamint a rizikófaktorok azonosítását [4]. Az időskori szédülés háttere multifaktoriális, ezek között szerepelnek a vestibularis végkészülék degeneratív elváltozásai, emellett szerepet játszanak az időskorral járó keringési eltérések, neurológiai betegségek, illetve a mozgásszervi eltéréseket okozó ízületi betegségek is [5]. Számos korábbi kutatás alapján a perifériás vestibularis eltéréseket jelölték meg az időskori szédülés fő okaként [6], ennek aránya 45-65\% között mozgott [7]. A leggyakoribb perifériás vestibularis eltérések közül a benignus paroxysmalis positionalis vertigo (BPPV), a Ménièrebetegség és a neuronitis vestibularis említhetők meg, ezek mellett lényegesek a centrális vestibularis laesiók is, különösen időskorban, a társuló vascularis rizikófaktorok következtében. Az extravestibularis eltérések közül kiemelendők a központi idegrendszer betegségei, a cardiovascularis eltérések, illetve a musculoskeletalis rendszer degenerációi. A társbetegségek következtében a pontos diagnózis tisztázása sok esetben nehézségekbe ütközik.

1. táblázat | A 65 év feletti és alatti, szédülés miatt vizsgált populáció demográfiai adatai

\begin{tabular}{lccc}
\hline & $\begin{array}{c}65 \text { év feletti } \\
\text { csoport }\end{array}$ & $\begin{array}{c}65 \text { év alatti } \\
\text { csoport }\end{array}$ & p-érték \\
\hline Nem (férfi/nó) & $13 / 23$ & $24 / 48$ & $0,94^{*}$ \\
Életkor (átlag \pm SD) & $72,78 \pm 4,6$ & $52,55 \pm 9,9$ & \\
\hline
\end{tabular}

*Khi-négyzet-próba.

SD = standard deviáció
A pontos diagnózis és a megfelelő terápia a szédüléses panaszok életminőségre kifejtett hatásai következtében lényeges [8].

Kutatásunkban az időskori szédülő populáció tüneteinek, diagnózisainak jellegzetességei mellett a panaszok életminőségre kifejtett hatását is elemezzük.

\section{Módszer}

\section{Betegcsoport}

Kutatásunkba a Semmelweis Egyetem Fül-Orr-Gégészeti és Fej-Nyaksebészeti Klinikájának Otoneurológiai Ambulanciáján megjelent, 65 év feletti, szédülést panaszoló betegeket vontuk be (13 férfi, 23 nőbeteg, átlagéletkor \pm $\mathrm{SD}, 72,78 \pm 4,6)$, akik kérdőíves felmérésben vettek részt. A vizsgált időszakban (2019. november-2020. december) megjelent 65 év alatti betegek számát figyelembe véve az időskori populáció a teljes beteganyag 29,6\%ának adódott. A két csoport értékeit az 1. táblázat tartalmazza.

Ahogy az 1. táblázatban látható, a nemek megoszlásának aránya nem különbözött a két csoportban, a női dominancia jellegzetes a szédüléses populációra.

\section{Kérdöív}

A kérdőív első részében általános kérdéseket tettünk fel a tünetekkel, a lehetséges provokáló faktorokkal, a társbetegségekkel kapcsolatban. A kérdőív második részében a DHI- (Dizziness Handicap Inventory) kérdőív magyar nyelvre lefordított változatát alkalmaztuk. Az utóbbi fizikális, funkcionális, valamint emocionális jellegű kérdéseket tartalmaz. „Igen” esetén 4, „néha” esetén 2, „nem” válasznál pedig 0 pont jár az adott kérdésekre. Az emocionális értékekból határozható meg a teljes DHI-pontszám, melynek maximális értéke 100 pont. A 16-34 pont enyhe, a 36-52 pont közepesen súlyos, az 54 feletti pontszám pedig súlyos életminőség-romlást jelez $[9,10]$.

\section{Statisztikai elemzés}

Az adatok statisztikai elemzését az IBM (Armonk, NY, Amerikai Egyesült Államok) SPSS V24-es programjának segítségével hajtottuk végre. Mivel a Shapiro-Wilk-teszt alapján a vizsgált értékek nem mutattak normáleloszlást, nemparametrikus tesztet (Mann-Whitney U-teszt) alkal- 
maztunk. Kategóriaelemzést a khi-négyzet-próba alapján végeztünk. Minden esetben $\mathrm{p}<0,05$ értéket tekintettünk szignifikáns különbségnek. A paraméterek eloszlásának ábrázolását boxplotok segítségével végeztük.

\section{Eredmények}

A vizsgált betegek körében a diagnózisok megoszlása az 1. ábrán látható.

Ahogy az 1 . ábrán látható, a vizsgált beteganyagon, a 65 év feletti betegek esetében dominált a Ménièrebetegség, valamint a centrális vestibularis eltérések. Ezen diagnózisok jellemzően 50 éves kor felett gyakoribbak, ezzel magyarázható az időskori populáción megfigyelhető gyakoriságuk. Kiemelendő ugyanakkor, hogy Otoneurológiai Ambulanciánkon a betegeket tervezett időpontban, átlagosan 3 hónapos előjegyzési idővel vizsgáltuk, ami befolyásolhatja a diagnózisok megoszlását.

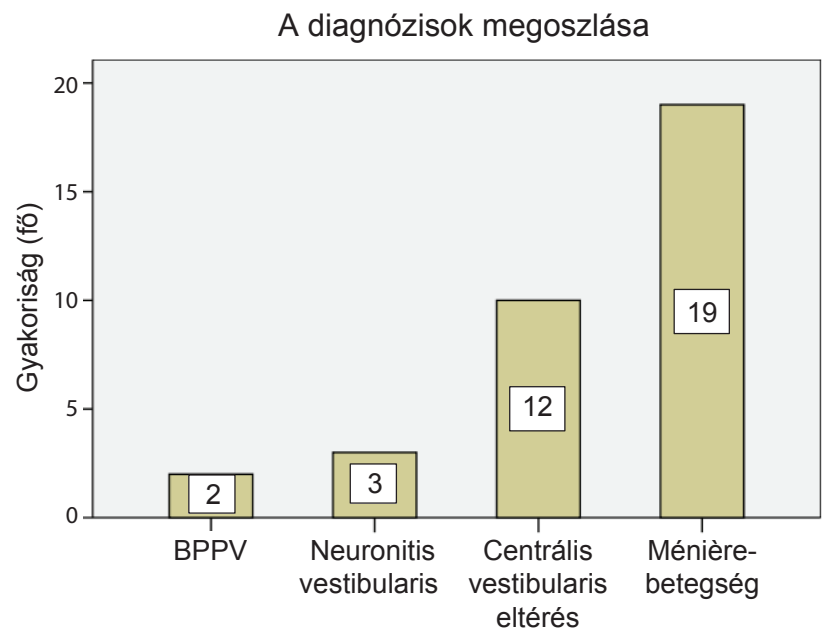

1. ábra

$$
\mid \begin{aligned}
& \text { Az egyes diagnózisok gyakorisága } \\
& \text { BPPV = benignus paroxysmalis positionalis vertigo }
\end{aligned}
$$

A tünetek erőssége (1-10)

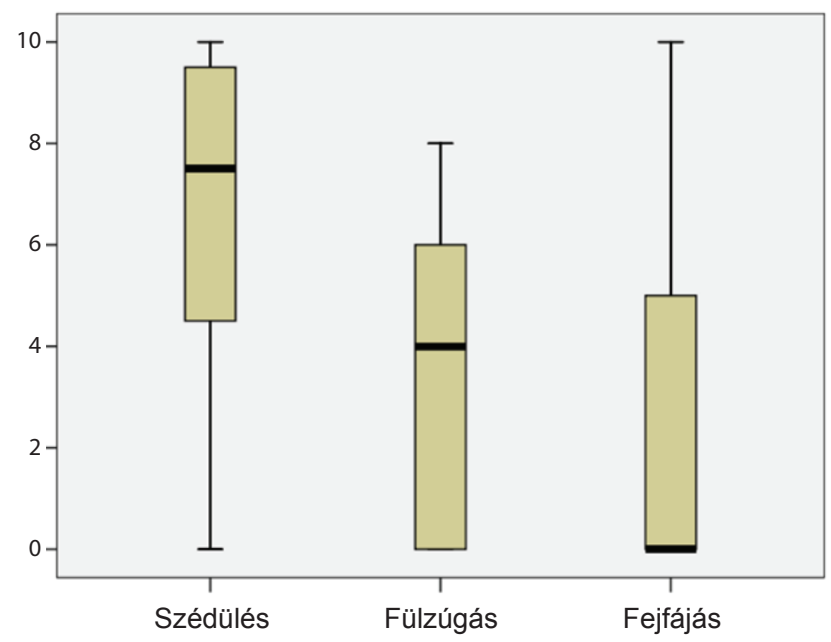

2. ábra $\mid$ A fö tünetek jellegzetességei (1-től 10-ig terjedő skála)
2. táblázat |A szédüléses epizódok időtartama

\begin{tabular}{lc}
\hline Szédülési idótartam & $\%$ \\
\hline Másodpercek & 13,8 \\
Percek & 19,4 \\
Órák & 27,8 \\
Napok & 27,8 \\
Folyamatos & 11,2 \\
\hline
\end{tabular}

A BPPV időskorban is gyakori, szédülést okozó betegségnek tekinthető, és ha a betegeket a szédülés akut szakaszában vizsgáltuk volna, feltehetően nagyobb gyakoriságot detektáltunk volna a BPPV tekintetében. A betegek tünetekkel kapcsolatos visszajelzését elemezve azt tapasztaltuk, hogy forgó és nem forgó jellegü szédülés fele-fele arányban jelent meg. Ahogy a 2. táblázatban látható, az órákig, illetve napokig tartó szédülés volt a leggyakoribb; az előbbi a Ménière-betegségre, az utóbbi pedig a centrális vestibularis eltérésekre jellemző. Ez alátámasztja a leggyakoribb diagnózisokat. A fó tünetek jellegzetességeit 1-tôl 10-ig terjedő numerikus skálán jellemeztük, és az eredményeket a 2. ábrán ábrázoltuk.

A 2. ábra mutatja, hogy a betegek 1-tól 10-ig terjedő skálán a szédülés kapcsán (átlag \pm SD, 6,25 $\pm 2,9$ ) adták meg a legnagyobb értékeket, ezt követte a fülzúgás $(3,6 \pm 2,6)$, végül a fejfájás $(2,6 \pm 2,8)$. Fejfájást 13 beteg panaszolt. Az egyes társuló tünetek gyakoriságát a 3. ábra foglalja össze.

A 3. ábrán látható, hogy a fülzúgás mellett a halláscsökkenés és a vegetatív tünetek (hányinger, illetve hányás) voltak a leggyakoribb társuló tünetek. Fülzúgás 21 beteg $(58,3 \%)$ esetén jelent meg, ennek 61,9\%-a egyoldali volt, ami az egyoldali Ménière-betegséggel magyarázható. A betegek 44,4\%-a panaszolt halláscsökkenést, elmondásuk alapján azonban ennek 27,7\%-a kapcsolódott közvetlenül a szédüléshez; ezekben az esetekben a

Kísérő tünetek

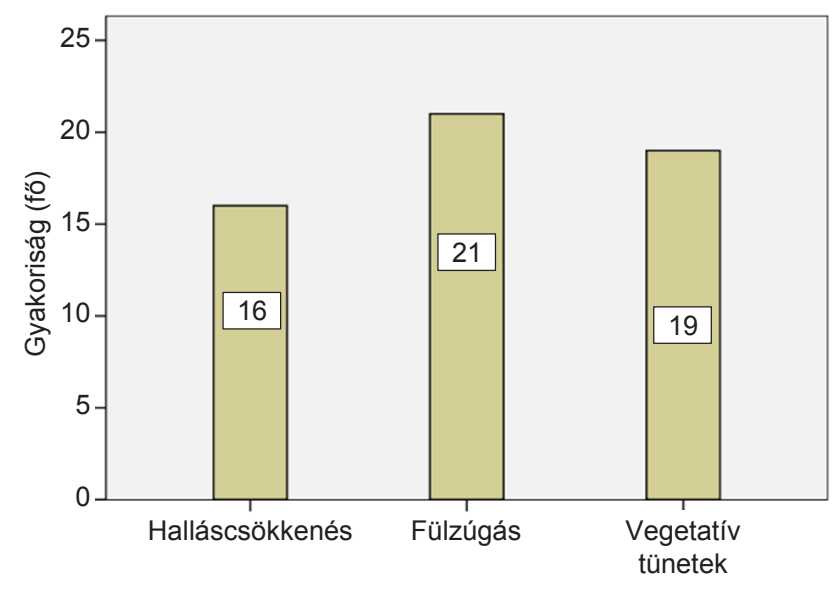

3. ábra 
halláscsökkenés döntően egyoldali volt. A többi esetben a hallásromlás hátterében presbyacusis feltételezhető; ezekben az esetekben kétoldali halláscsökkenést detektáltunk, és a hallásromlás nem akutan alakult ki. Fejájás 36,1\%-ban jelentkezett, ez részben magyarázható a központi idegrendszeri eltérésekkel, ugyanakkor tünete lehet a Ménière-betegségnek is. Erre utal egy korábbi kutatás eredménye, melyben a Ménière-betegek 49\%-ánál jelentkezett fejfájás [11]. Az életminőség szempontjából különösen meghatározók a vegetatív tünetek. A vizsgált beteganyagon hányinger 44,4\%-ban, míg hányás 27,7\%ban kísérte a panaszokat. A társtünetek esetén rákérdeztünk, hogy erősségük hogyan viszonyul a vezető tünet (szédülés) intenzitásához. A betegek döntő többsége $(69,44 \%)$ a kísérő tünetek és a szédülés erősségét azonosnak írta le, a társuló tüneteket kifejezettebnek leíró betegek aránya viszont igen alacsony volt $(2,78 \%)$.

Társbetegségek

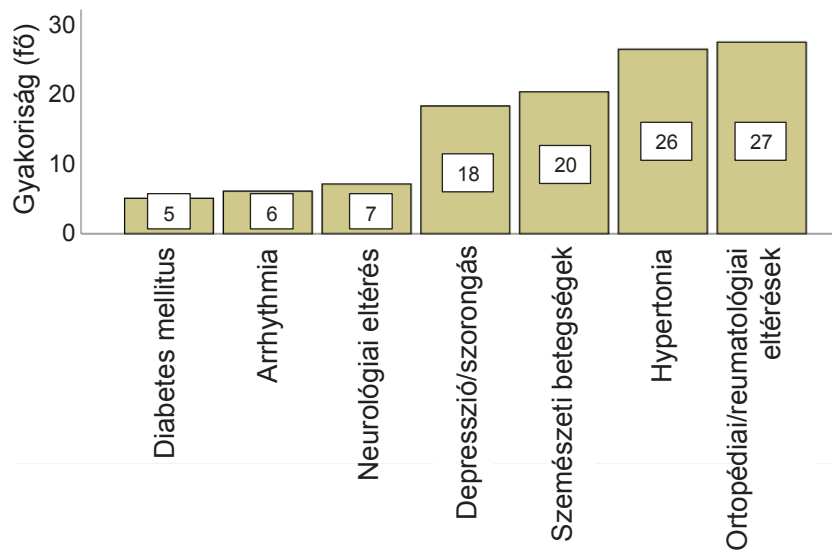

4. ábra $\quad$ A vizsgált populáción megjelenő társbetegségek

DHI-értékek

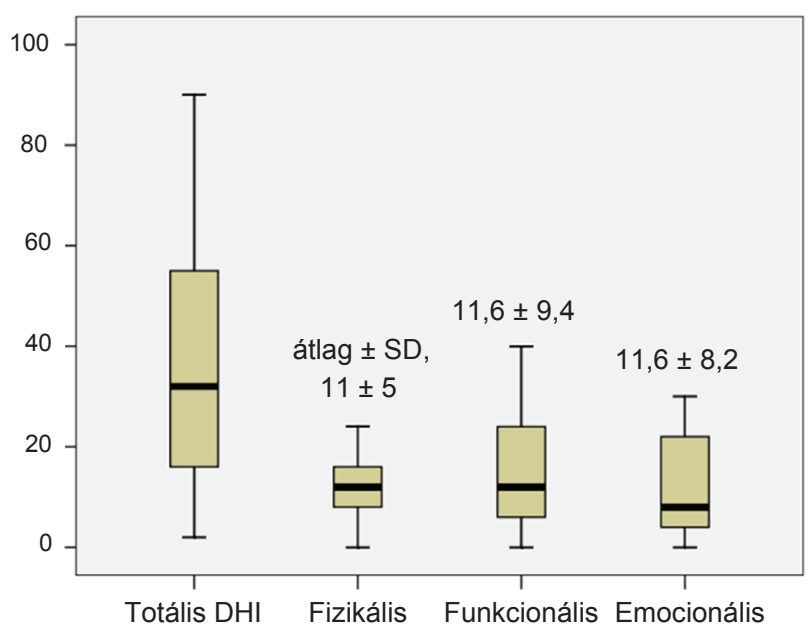

\begin{tabular}{l|l} 
5. ábra & $\begin{array}{l}\text { Az egyes DHI-pontértékek megoszlása } \\
\text { DHI }=\text { szédülésterheltségi skála; } S \mathrm{SD}=\text { standard deviáció }\end{array}$
\end{tabular}
A 4. ábrán jelöltük a vizsgált populáción megjelenő társbetegségeket.

A 4. ábra mutatja, hogy a vizsgált idős, szédülő populáción számos társbetegség jelent meg. A gyakoriság alapján látható, hogy ezek közül a leggyakoribbak az ortopédiai és reumatológiai eltérések, a hypertonia, valamint a szemészeti betegségek. Ezek szédülésre kifejtett hatása lényeges, hiszen az érzőrendszer funkcióinak csökkenése, a mozgás beszúkülése mind befolyásolják a tüneteket. A depresszió és a szorongás különösen lényeges az érintett betegek életminősége szempontjából. Ennek felmérésére alkalmazható a DHI-kérdőív, melynek eredményeit az 5. ábrán foglaltuk össze.

Ahogy az 5. ábrán látható, a totális DHI-értékek megoszlása alapján a betegek a normál-életminőségtől egészen a súlyos életminőség-romlás kategóriájáig adtak meg értékeket. Az egyes pontszámok alapján elmondható, hogy a fizikális, funkcionális és emocionális értékek egyaránt érintettek voltak, és ezek megoszlása között a boxplot alapján számottevő különbség nem volt.

A 3. táblázat adatai szerint normál-életminőség csupán a betegek 22,2\%-ában fordult elő, 77,8\%-ukban valamilyen fokú életminőség-romlással számolhattunk. Ezek közül a leggyakoribb kategóriák az enyhe, valamint a súlyos életminőség-romlás voltak. Kiemelendő, hogy a beteganyag 30\%-a jelzett súlyos életminőség-romlást.

3. táblázat |A DHI-kategóriák megoszlása

\begin{tabular}{lc}
\hline Kategória (pont) & Esetszám $(\mathrm{n})$ \\
\hline Normál $(0-15)$ & 8 \\
Enyhe $(16-34)$ & 11 \\
Közepes $(36-52)$ & 6 \\
Súlyos $(54<)$ & 11 \\
\hline
\end{tabular}

DHI = szédülésterheltségi skála

\section{Megbeszélés}

Kutatásunkban elsősorban az időskori szédülő populáció tünetekkel kapcsolatos jellegzetességeit, illetve a panaszok életminőségre kifejtett hatását vizsgáltuk. Meglepő módon a vizsgálat időtartama alatt a szakambulancián megjelenő betegek kb. 30\%-a volt 65 év feletti, ez valószínúleg a COVID-19-pandémia hatásainak tudható be. Korábbi kutatások alapján elmondható, hogy a szédüléses panaszok gyakorisága a korral arányosan növekszik, illetve a betegcsoportban női dominancia figyelhető meg [12], ami a saját vizsgált beteganyagunkon hasonlóképpen alakult. A megfelelő diagnózis és az adekvát kezelés lényeges, egyrészt az életminőség, másrészt az olyan lényeges következmények, mint például az esés szempontjából, melyre időskorban magasabb rizikó figyelhető meg. Korábbi kutatások eredménye alapján erre az egyensúlyzavarokkal küzdő, szédülő időskori betegeknek nagyobb az esélyük [13]. Saját betegcsoportunk 
visszajelzése alapján visszatéró esések 14 betegnél fordultak elő, ez mind a betegek biztonsága, mind az életminőség szempontjából fontos.

Több szerző is felhívta a figyelmet a szédülés életminőségre kifejtett hatására időskorban, a háttérben álló etiológiától függetlenül [14]. Ugyanakkor lényeges, hogy megfelelő diagnózis hiányában az életminőség még kifejezettebb romlásával kell számolni. Korábbi eredmények alapján a konkrét diagnózis az esetek 20-40\%-ában hiányzott, aminek oka feltehetően multifaktoriális [15]. Ebből a szempontból lényeges viszont az időskori szédüléses panaszok „időskori szindrómaként” való kezelésének mellőzése [3]. Különösen azokban az esetekben, amikor a háttérben nehezebben definiálható, extravestibularis okok állnak, magas a rizikó a szorongás, a depresszió, a szociális izoláció, illetve az agorafóbia tekintetében. A vizsgált betegcsoport kb. 50\%-án azonosították az imént említett eltéréseket [16]. Saját betegcsoportunk esetén minden beteg konkrét, vestibularis rendszert érintő diagnózissal rendelkezett; ezzel együtt a betegek nagyobb része jelzett vissza életminőség-romlást, ennek 30\%-a a súlyos kategóriába esett, a DHI-kérdőívek eredménye alapján. Korábbi eredmények alapján perifériás vestibularis eltérés 73,8\%-ban, míg centrális 26,2\%-ban jelentkezett [7]. Ez a saját beteganyagunkon $66,7 \%$, valamint 33,3\% értéknek adódott, így az eredmények hasonlónak mondhatók. A vizsgált, 65 év feletti betegcsoporton a leggyakoribb diagnózisok a Ménière-betegség és a centrális vestibularis eltérések voltak, ellentétben a 65 év alatti betegekkel, akiknél egyértelmüen a BPPV a leggyakoribb, a második pedig a neuronitis vestibularis [17]. A Ménière-betegség incidenciája korábbi eredmények alapján 60 éves kor felett emelkedik [18], a centrális eltérések gyakorisága pedig az időskori vascularis rizikófaktorokkal magyarázható [19]. A tünetekre gyakorolt hatásuk miatt számos társbetegség rizikófaktornak tekinthető. Egy korábbi kutatás eredménye alapján - a legfontosabbakat említve - szignifikáns összefüggést detektáltak például a cardiovascularis eltérések, az osteoporosis, a depresszió, valamint az alvászavarok és a szédülés között [20]. Saját eredményeink alapján a mozgásszervi eltérések, a hypertonia, a szemészeti betegségek, valamint a depresszió és a szorongás voltak a leggyakoribbak.

A szédülésen kívül számos kísérő tünet megjelenését tapasztaltuk, ezek közül domináltak a cochlearis, valamint a vegetatív tünetek. Halláscsökkenés az esetek 44,4\%-ában jelent meg, ami az esetleges szociális izoláció, illetve az életminőség szempontjából szintén fontos. Egy korábbi tanulmány magasabb arányt talált, a betegek 23,2\%-a esetén mértek kornak megfelelő hallást, $41,5 \%$ esetén a magas frekvenciákon, $26,2 \%$ esetén a magas és a mély frekvenciákon is detektáltak hallásromlást [7]. Egy nagy esetszámú vizsgálat alapján 65 év felett krónikus fülzúgás a betegek $32 \%$-a esetén jelent meg, ugyanakkor eredményeik alapján nem volt szignifikáns összefüggés a fülzúgás és a szédülés előfordulása között
[21]. A fülzúgás megjelenése, szédüléssel együtt vagy attól függetlenül, mindenképp jelentős életminőségi szempont. A társuló vegetatív tünetek is egyértelmúen befolyásolják az életminőséget, és korábbi eredmények alapján bizonyos esetekben befolyásolják a betegek szédülésének megélését [22].

\section{Következtetés}

Az időskori szédülés lényeges a beteg romló életminősége szempontjából. A társuló komorbiditások mellett a háttérben álló vestibularis eltérések kizárása, illetve diagnosztizálása fontos feladat. Ennek függvényében tervezhető a terápia, amely kapcsán a kísérő tünetekre is fontos hangsúlyt fektetni. Így az érintett betegek életminősége javítható.

Anyagi támogatás: A közlemény megírása, illetve a kapcsolódó munka anyagi támogatásban nem részesült.

Szerzôi munkamegosztás: M. A.: Adatgyüjtés, statisztikai elemzés, a cikk megírása. F. M.: Adatgyưjtés, a kérdőívek kiosztása és elemzése. M. S.: Adatgyújtés, kritikai megjegyzések. Sz. Á.: Témavezető, a beteganyag biztosítása, a kutatás folyamatos szakmai felügyelete és szupervíziója, kritikai véleményezés. T. L.: Szakmai véleményezés. A cikk végleges változatát az összes szerző elolvasta és jóváhagyta.

Érdekeltségek: A szerzőknek nincsenek érdekeltségeik.

\section{Irodalom}

[1] Furman JM, Raz Y, Whitney SL. Geriatric vestibulopathy assessment and management. Curr Opin Otolaryngol Head Neck Surg. 2010; 18: 386-391.

[2] Jönsson R, Sixt E, Landahl S, et al. Prevalence of dizziness and vertigo in an urban elderly population. J Vestib Res. 2004; 14: 47-52.

[3] Drachman DA. Occam's razor, geriatric syndromes, and the dizzy patient. Ann Intern Med. 2000; 132: 403-404.

[4] Salles N, Kressig RW, Michel JP. Management of chronic dizziness in elderly people. Z Gerontol Geriatr. 2003; 36: 10-15.

[5] Szirmai Á. Vertigo in elderly. In: Répássy G. (ed.) Otorhinolaryngology and head and neck surgery. [Szédülés időskorban. In: Répássy G. (szerk.) Fül-orr-gégészet, fej-nyaksebészet.] Medicina Könyvkiadó, Budapest, 2011; pp. 207-208. [Hungarian]

[6] Iwasaki S, Yamasoba T. Dizziness and imbalance in the elderly: age-related decline in the vestibular system. Aging Dis. 2014; 6: 38-47.

[7] Mangabeira Albernaz PL. Vertigo in elderly patients: a review of 164 cases in Brazil. Ear Nose Throat J. 2014; 93: 322-330.

[8] Ciorba A, Bianchini C, Scanelli G, et al. The impact of dizziness on quality-of-life in the elderly. Eur Arch Otorhinolaryngol. 2017; 274: 1245-1250.

[9] Maihoub S, Molnár A, Csikós A, et al. What happens to vertiginous population after emission from the emergency department? [Mi történik a szédülő beteggel a sürgősségi osztály elhagyása után?] Ideggyógy Szle. 2020; 73: 241-247. [Hungarian] 
[10] Jacobson GP, Newman CW. The development of the Dizziness Handicap Inventory. Arch Otolaryngol Head Neck Surg. 1990; 116: 424-427.

[11] Radtke A, Lempert T, Gresty MA, al. Migraine and Ménière's disease: is there a link? Neurology 2002; 59: 1700-1704.

[12] Ekwall A, Lindberg A, Magnusson M. Dizzy - why not take a walk? Low level physical activity improves quality of life among elderly with dizziness. Gerontology 2009; 55: 652-659.

[13] Stel VS, Pluijm SM, Deeg DJ, et al. A classification tree for predicting recurrent falling in community-dwelling older persons. J Am Geriatr Soc. 2003; 51: 1356-1364

[14] Lasisi AO, Gureje O. Disability and quality of life among community elderly with dizziness: report from the Ibadan study of ageing. J Laryngol Otol. 2010; 124: 957-962.

[15] Dros J, Maarsingh OR, Beem L, et al. Impact of dizziness on everyday life in older primary care patients: a cross-sectional study. Health Qual Life Outcomes 2011; 9: 44.

[16] Mira E. Improving the quality of life in patients with vestibular disorders: the role of medical treatments and physical rehabilita tion. Int J Clin Pract. 2008; 62: 109-114.

[17] Seidel DU, Park JJ, Sesterhenn AM, et al. Demographic data and seasonal variation in peripheral vestibular disorders in ENT practices in Germany. J Vestib Res. 2019; 29: 181-190.
[18] Yang TH, Xirasagar S, Cheng YF, et al. Peripheral vestibular dis orders: nationwide evidence from Taiwan. Laryngoscope 2021; 131: 639-643.

[19] Szirmai A, Küstel M, Pánczél G, et al. Evidences of vascular origin of cochleovestibular dysfunction. Acta Neurol Scand. 2001; 104: 68-71.

[20] Gassmann KG, Rupprecht R. Dizziness in an older community dwelling population: a multifactorial syndrome. J Nutr Health Aging 2009; 13: 278-282

[21] Chang NC, Dai CY, Lin WY, al. Prevalence of persistent tinnitus and dizziness in an elderly population in Southern Taiwan. J Int Adv Otol. 2019; 15: 99-105.

[22] Molnár A, Maihoub S, Fent Z, et al. Typical characteristics of the symptoms of patients suffering from Ménière's disease and the multidisciplinary approach. [A Ménière-betegség tüneteinek jellegzetességei és a multidiszciplináris megközelítés.] Orv Hetil. 2019; 160: 1915-1920. [Hungarian]

(Molnár András dr., Budapest, Szigony u. 36., 1083 e-mail: andrasm94@gmail.com)

\section{PÁLYÁZAT}

A Prof. Dr. Romics László Akadémikus Emlékére Alapítvány pályázatot hirdet Magyarországon dolgozó, magyar állampolgárságú, 40 éven aluli orvosok és orvosbiológiai kutatással foglalkozó személyek számára. A nyertes pályázó(k) között 500000 Ft alapítványi adomány, illetve különdijak kerülnek kiosztásra.

A pályázat célja: a klinikai gyógyítás, vagy orvosi tudományos kutatás területén dolgozók kiemelkedő tudományos tevékenységének elismerése.

Előnyt élveznek azok a pályázók, akik az Alapítvány névadójának munkásságát folytatva cardiovascularis és anyagcsere-betegségek területéről nyújtanak be pályázatot.

A pályázat benyújtásának határideje: 2022. február 28. (elbírálásának határideje: 2022. április 30.)

A pályázatot a palyazat@romicsalapitvany.hu e-mail címre elektronikus aláirással ellátva (ügyfélkapuval létrehozott AVDH aláirás is megfelelö), PDF formátumban kell benyújtani.

A pályázatot természetes személy, saját nevében, magyar nyelven nyújthatja be, a pályázati anyag ábrák nélkül maximum 15.000 leütés (karakter) terjedelmü lehet. A pdf fájl mérete nem haladhatja meg a $25 \mathrm{MB}$-ot. A pályázathoz a fentiekhez azonos módon, külön pdf formátumú fájlban mellékelni kell rövid szakmai életrajzot, a születési idő, lakcím és telefon elérhetöségek megjelölésével. A szakmai önéletrajz végén nyilatkozni kell, hogy a pályázó a közölt személyes adatoknak a Romics Alapítvány által történő kezeléséhez hozzájárul, tudomásul veszi, hogy a Kuratórium minden tagja megismerheti adatait és pályázatát. A pályázatot papíron kinyomtatott formában nem kell megküldeni.

Az Alapítvány adatairól, müködéséröl az alapítvány honlapján - www.romicsalapitvany.hu - található információ.

A cikk a Creative Commons Attribution 4.0 International License (https://creativecommons.org/licenses/by/4.0/) feltételei szerint publikált Open Access közlemény, melynek szellemében a cikk bármilyen médiumban szabadon felhasználható, megosztható és újraközölhető, feltéve, hogy az eredeti szerző és a közlés helye, illetve a CC License linkje és az esetlegesen végrehajtott módosítások feltüntetésre kerülnek. (SID_1) 